Perera L.T.D., Wanigasekara W.A.D.K.J., \& Priyadarshani G.K.N., Wayamba Journal of Management 12 (1)

\title{
Does Board Characteristics Affects Corporate Financial Leverage? Evidence from Non-Financial Companies Listed in Colombo Stock Exchange
}

\author{
L.T.D. Perera ${ }^{1}$, W.A.D.K.J. Wanigasekara ${ }^{2}$ \& G.K.N. Priyadarshani ${ }^{3}$ \\ ${ }^{1,2,3}$ Department of Accountancy \\ Wayamba University of Sri Lanka \\ SRI LANKA \\ ${ }^{1}$ tehandanushkaperera@gmail.com, ${ }^{2}$ kaushalya@wyb.ac.lk, \\ niluka@wyb.ac.lk
}

\begin{abstract}
With the recent developments in the discipline of corporate governance, concern for the Board of Directors has increased significantly. Even though there are a number of extensive researches in the field, the understanding of the board and its impacts on corporate Financial Leverage is still limited. This research investigated the linkage between some corporate governance characteristics and corporate Financial Leverage in an emerging market, Sri Lanka. The researchers have used a sample of 100 non - financial highly market capitalized firms selected from the most active trading listed Companies in Colombo Stock Exchange (CSE) covering the period from 2011 to 2019 with 900 observations. The Fixed effect multiple regression models (OLS) have used to analyze the data. Results show that proportionate of board non-executive directors and independent directors positively significantly affect the corporate financial leverage and CEO Duality and Board tenure have negatively significantly affected the corporate financial leverage.
\end{abstract}

Keywords:- Corporate Governance, Corporate Financial Leverage, Colombo Stock Exchange

\section{INTRODUCTION}

This research investigates the linkage between board characteristics and corporate financial leverage of nonfinancial listed companies in the Colombo Stock Exchange (CSE). After some financial corporate scandals, lots of strategies and methods are taken into the field of corporate governance in order to build up effective governance mechanisms. With the significant developments in the discipline of corporate governance, concern for the board of directors has increased significantly. Financial related activities usually connected with the senior management of the firm. Some large companies have their 
separate treasury and controlling departments. In order to achieve their financing strategies they made financial plans. Financial planning is a mechanism where, how the organization determines their capital requirements by considering internal and external factors. This is how an organization framing of financial policies about their working capital requirements and potential investments. Financial fund forecasting establishes guideline for change and growth in a firm, which concern the major elements of a firm's financial and investment policies without examining the individual component of those policies in details. (Ross, Thompson, Christensen, Westerfield, \& Jordan, 1994). In Sri Lankan context board of directors are appointed by the shareholders and they act for the sake of shareholders. Managers of the firm doing what the board of directors dictated, this is called the "Anglo-Saxon model". Corporate governance mechanism of Sri Lanka is significantly differ from the "Anglo-Saxon" system, when considering an ownership perspective and a banking relationship perspective. (Wellalage \& Locke, 2012). In Sri Lanka, most of the firms, even those are listed or non-listed companies they are tend to rely on Bankers when they want financial support and they do not consider other sources of capital funding. Some other researchers founded that the level of corporate debt in Sri Lanka is considerably less than developed countries corporate debt levels(Colombage, 2007). Company directors are taking decisions and the decision taken by the directors of the company have a significant impact on capital structure. The combination of debt and equity affects the achievements of the firms and firm's corporate Financial Leverage (Abobakr \& Elgiziry, 2015). Most of the corporate governance researches have based on the experience of developed countries such as United States and other European economies. In developing countries corporate governance mechanism is scarce and therefore, in Sri Lanka, awareness of corporate governance is still limited or even non-exist. Most of Sri Lankan researches highly focused to determined relationship between board characteristics and capital structure decisions in listed manufacturing firms in Sri Lanka. (Wellalage \& Locke, 2012), (Achchuthan, Kajananthan, \& Sivathaasan, 2013) and some of researchers (Dissanayake \& Dissanayake, 2019), (Ajanthan, 2013) have identified how board characteristics effect to the firm performance in listed manufacturing firms in Sri Lanka. Further some researchers in Sri Lanka have identified determinant of leverage with reference to the listed manufacturing companies in Sri 
Lanka (Vijeyaratnam \& Anandasayanan, 2015). Accordingly majority of corporate governance researches are focused on the direct relationship of board characteristics with corporate outcomes and they do not consider about effects on some of intervening variables such as Corporate Financial Leverage. Based on the research gap identified, this study investigates the affect of board characteristics on corporate financial leverage of non-financial companies listed in Colombo stock exchange.

This study gives a border idea about, how company can use corporate governance practices regarding to the composition of board of directors for adding additional value to the entity as a whole. Further, the research contributes to fill the existing gap by providing evidence of the relationship between board characteristics on corporate Financial Leverage in Sri Lankan listed non-financial companies. Board of directors of the company are considering one of the main tools of internal governance mechanism. Board effectiveness on corporate governance may differ according to the board features and therefore, the results may help firms to take proper decisions regarding the appointment of board members.

\subsection{Research Problem}

Since, most of the researchers have not focused on impact of board characteristics on corporate financial leverage, researchers have identified research problem as,

"Does Board Characteristics affects Corporate Financial Leverage?"

\subsection{Research Questions}

Researchers have identified followings as a research questions.

1- Does board size affect significantly and positively to corporate financial leverage?

2- Is there a significant negative impact of proportion of females on the board on corporate financial leverage?

3- Does proportion of board nonexecutive directors affect significantly and positively to corporate financial leverage?

4- Does board independence affect significantly and positively to corporate financial leverage?

5- Is there a significant positive impact of CEOs duality on corporate financial leverage?

6- Does board tenure affect significantly and positively to corporate financial leverage? 


\subsection{Research Objectives}

In this study researchers have mainly identified following objectives,

\subsubsection{Main Objective}

To identify the impact of board characteristics on corporate financial leverage

\subsubsection{Sub objectives}

1- To identify the impact of board size on corporate financial leverage

2- To investigate the impact of proportion of females on the board on corporate financial leverage

3- To examine the impact of proportion of board nonexecutive directors on corporate financial leverage

4- To identify the impact of board independence on corporate financial leverage

5- To examine the impact of CEOs duality on corporate financial leverage

6- To investigate the impact of board tenure on corporate financial leverage

The subsequent sections of the article analyze the theoretical and empirical reviews and developed hypotheses of the researches and then discusses the data, variables, methods, procedures, findings, conclusion and the recommendations are also discuss thereon.

\section{LITREATURE REVIEW AND HYPOTHESES}

In the Literature Review, one by one describing, summarizing, objectively evaluating and clarifying of previous research findings and theoretical aspects in order to gather good sense of knowledge.

\subsection{Theoretical Framework}

For the success and getting support for the conclusion, it is important to follow up theories derived by some experts. According to that, following theories are important in explaining Financial Leverage, capital structure and financial performance of the company.

\subsubsection{Modigliani-Miller (MM) Theory}

The modern corporation has no "owners" instead of that it is an interconnected set of contracts among the several of stakeholders. They are shareholders, lenders, employees, managers, suppliers \& distributors. They all are getting decisions toward the success of the firm. The perfect combination of capital structure financing is critical factor to company success(John \& Campbell, 1999). The theory of Modigliani-Miller (MM) states that, in a world without taxes, firms are 
indifferent to capital structure and, in a world of corporate taxes where there is no financial distress costs, all firms should be 100 percent debt-financed. In the corporate world, firm's management shall consider tax impact, cost of financial distress as well as agency cost. Since, a firm may issue debt capital only up to the certain point. When financial distress becomes a real threat beyond that certain level, the firm might issue equity capital instead of debt capital.(Ross, Westerfield, \& Jaffe, 2005).

\subsubsection{Agency costs and capital Structure}

\section{Agency costs of debt}

The agency costs of debt include overseen and control expenditure in order to ensure that the stakeholders as well as discount at which the bond of more leveraged companies sell do not exploit bondholders. Further, it includes cost arising as a results of loans taken by the company which will reduced the flexibility of operation and investment ability. Agency cost of debt reduces amount of debt including firm's capital structure due to conflict of interest and cost will increase with corporate financial leverage (Shapiro \& Balbirer, 2000).

\section{Agency cost of equity}

When outside equity increases consequence agency cost of equity rise. There is a trade-off in-between agency cost of equity and agency cost of outside equity. When adding more outside equity capital in to the capital structure management interest over the firm diminish with its stake in the firm. One extreme, if management owes entire percentage of ownership to having no interest, desire to forth the effort and risk taking in order to maximize shareholder wealth dramatically change.

\subsubsection{Resource dependency theory}

Resources are always not readily available for obtained and it may be scarce or under the control of uncooperative actors. Resulting of this will create differences in power and access to the resources. To eliminate this resource dependencies, firms develop sound business strategies and internal structures to enhance organizations' bargaining power with regard to resource related transactions. It includes developing sound supplier relationship, diversification of current business sector and increasing scale of production. Some strategies such as diversification of current production portfolio can mitigate the dependence on other business sectors and it enable to increase its power and leverage. Typically an organization maintain and adjust their business strategies to keep power full relationship with other entities. Increasing 
uncertainty of resources and level of dependence will increase needs for keep sound relationship with other companies. Resource dependence theory more focuses on functions of board of directors with regard to providing different ways to resources required by the firm. This is demonstrating that the directors of the company providing or secure the required resources to the company by using there linkage with external environment.

\subsubsection{Pecking - Order theory}

When firm needs to raise new capital, company may faces choice between whether issuing debt capital or equity capital. To reach final conclusion company can depend on agency costs, distress costs or amount of tax benefits. Before the implementation of laws regarding to inside dealing managers unfairly have used their prospect prior to equity issuance. Even today, managers are willingness to issue equity shares after the price of stock has risen since, timing is very important motivation to get decision of equity issuance. Managers must know about company prospect than typical investors. If managers' estimation about company is not better than typical investors does, any attempts may take by the management not succeed. Accordingly, when stocks are undervalue, straightforwardly company can issue debt capital instead of equity capital and further company can issue debt capital even though firm is overvalued. Ultimately if company issue equity shares to the public, investors are thinking that the firm's stock prices are overvalued. Therefore, investors will not buy shares until they realized company do not gain any advantages from equity issuance. End of this no one issue equity and instead of that company issue debt capital and this will cause to increasing financial leverage of the company.

In real world, finance managers must consider tax benefits, agency costs and financial distress cost prior to make their decisions. Firms may issue debt capital up to the certain point and if financial distress become real possible then beyond that company should issue equity capital (Ross, Westerfield, \& Jaffe, 2005).

\subsection{Empirical Review}

\subsubsection{Board Size}

Previous researchers have found and suggested that board size and directors appointed to the board from outside are positively related to the total debt ratio and some control variables such as profitability and liquidity are negatively related to the total debt ratio (Sheikh \& Wang, 2012). Leverage is only variable that creates significant negative impact on company performance. Further researcher have found 
Board composition and Board size positively correlated with the debt ratio in sample of 28 Sri Lankan manufacturing companies. (Dissanayake \& Dissanayake, 2019). Nevertheless, by using 18 listed Sri Lankan manufacturing companies' researchers found that there are negative relationship between Board Size, Board Independence with Debt Ratio (Ajanthan, 2013). Tangibility, firm size and firm growth have significant effect in capital structure decision in Sri Lankan companies. manufacturing Accordingly, researchers have found leverage decision influenced only by firm Size, firm growth in service companies while leverage decision of manufacturing companies influenced by only profitability

variables(Buvanendra, 2013). Proportionate of Non-Executive directors, leadership style of the management, board meetings and board size creates positive relationship with leverage in Sri Lankan listed manufacturing companies.(Rajendran, 2012).

Further, board size and board independence positively, significantly affect the corporate financial leverage (Hanh Song \& Nguyen, 2019).

Accordingly researchers have developed the first hypothesis for the study as,
H1: There is a significant positive impact of board size on corporate financial leverage.

\subsubsection{Females on the Board}

When the female directors are present on the board, it has been reducing the information asymmetry and managerial missed behaviors (Usman, Farooq, Zhang, Majid Makki, \& Khan, 2019) presence of the females on the board changing the behavior of male directors on the board (Ahern \& Dittmar, 2011). Gender diversity with positive relationship on financial leverage, agreed resource dependence theory and it indicates when firms have a diversified board characteristics it gives the firms advantages to having external funds and gain tax shield benefits (Monther, 2015). However, higher level of board diversification may result positive relationship with leverage (Lückerath-Rovers, 2013) and again this accepted by (Alvesa \& Couto, 2014).

Risk averse female directors in the board keep lower level debt ratio compare with other companies that do not have female representation in the board (Harris, 2014). Further, researchers found that having more proportionate of female directors will result lower level of insolvency risk (Wilson \& Altanlar, 2009). 
Accordingly researcher has developed the second hypothesis as,

$\mathrm{H} 2$ : There is a significant negative impact of proportion of females on the board on corporate financial leverage

\subsubsection{Non-Executive Directors}

Higher proportionate of NonExecutive directors seems have easier access to the loans and therefore, applied a higher level of leverage and higher level of debt. According to the Stewardship theory CEO duality decreases the communication struggles and creates a clear sense of centralized decisionmaking (Vakilifard, Gerayli, Yanesari, \& Ma'toufi, 2011) (Mokarami , Ahmadi, \& Hosseinzadeh, 2012). NonExecutive directors are accountable to shareholders of listed manufacturing firms in Sri Lanka since, they have leading higher debt policy (leverage) (Wellalage \& Locke, 2012). Same positive relationship has been identified by (Rajendran, 2012) in Sri Lanka. Further, this is confirmed by (Hsien, Wang , \& Liu, 2012). When there is as fidelity or loyalty management, then can be expect negative relationship with financial leverage (Jensen, 1986).
Accordingly, researchers have developed the third hypothesis as,

H3: There is a significant positive impact of proportion of board non-executive directors on corporate financial leverage

\subsubsection{Independent Non- Executive Directors}

In the Sri Lankan study, it was found that board independence has negative relationship with financial leverage (Ajanthan, 2013). Board independence positively, significantly affect the Corporate Financial Leverage (Hanh Song \& Nguyen, 2019). Outside directors positively related to the total debt ratio and long term debt ratio(Nadeem \& Zongjun , 2012) According to the resource dependence theory indicates that the Independent directors positively affect to the debt ratio due to the outside relationship that they have with debt providers.

Accordingly, researchers have developed the next hypothesis as,

$\mathrm{H} 4$ : There is a significant positive impact of Board independence on corporate financial leverage

\subsubsection{CEOs Duality}

CEO Duality creates positive relationship with Corporate Financial leverage and this has confirmed stewardship theory, since clear centralized decision making (Abor, 2007).Same 
positive relationship with corporate finance leverage have identified by (Vakilifard, Gerayli, Yanesari, \& Ma'toufi, 2011) and (Mokarami, Ahmadi, \& Hosseinzadeh, 2012). When CEO is holding dual responsibility it will lead to take immediate decisions and have a positive relationship with leverage (Uddin, UddinKhan, \& Mosharrof, 2019). This positive relationship confirmed by (Uwalomwa, 2014).

Accordingly, researchers have developed the fifth hypothesis as,

H5: There is a significant positive impact of CEOs duality on corporate financial leverage.

\subsubsection{Board Tenure}

When board has not effective industry experience, it lead maintaining a lower level of leverage. When board has sound industrial experience lead positive impact to the leverage. (Tarus \& Ayabei, 2015). When board of directors have sound experience in the industry they will come across with superior monitoring abilities they are encouraging debt capital to increase firm value. Since, board tenure have positive relationship with corporate financial leverage. This has been confirmed by pecking - Order theory.
Accordingly, researchers have developed the last hypothesis as,

H6: There is a significant positive impact of board tenure on corporate financial leverage.

\section{METHODS}

\subsection{Sample and Data}

This research focused on the factors influencing corporate Financial Leverage of an entity that are public listed in Colombo stock exchange. For logically conducting this research, researcher selects actively trading, listed companies that are registered in Main board and Dirisavi board covering nine year of assessments for each selected companies. The Colombo Stock Exchange (CSE) has 289 companies representing 20 Global Industry Classification Standards (GICS) industry groups as at 20th January 2020, with a Market Capitalization of Rs. 2,748.10 Bn. According to the CSE Data base there are 48 Diversified Listed Financial Companies, 11 Listed Banks, and 10 Listed Insurance Companies \& 19 Real Estate Companies.(Exchange, 2019). After removing all financial companies, population is limited to 201 listed entities \& from that, 100 most actively highest market capitalized trading non-financial listed companies selected as the sample of this study and total sample covers, approximately $50 \%$ to the total population. The 
reason for the selection of NonFinancial Companies for the study is financial sector companies are different in terms of company assets, an operating functions, and regulatory requirements of manufacturing sectors. Further, financial companies excluded from the analysis because of the differences in Leverage and corporate governance mechanism in between these and other industries (Berge, Ofek, \& Yermack, 1995). In this study researchers have removed banks, insurance companies and leasing companies and real estates. This has confirmed by (Thi Pham \& Nguyen, 2019), (Uddin, UddinKhan, \& Mosharrof, 2019). When selecting of the sample manufacturing companies, which did not start their operations before, 2011 excluded in sample size. The sample has selected under purposive sampling method and sample includes both financially strong and weak companies but companies that find financial discrepancies excluded from the sample because of the probability of bankruptcy, which can have a significant impact on the company's financing decisions. Required non-financial and financial data is obtained from a Data Stream database and Companies Annual Reports. Sample period for the current study was selected period covering 2011 to 2019

\subsection{Variables}

In this study independent variables are Board Size, NonExecutive Directors, Independent Directors, Board Gender diversity (Number of Female Directors on Board), CEO Duality and Board Tenure and Dependent variable is Corporate Financial Leverage. For the study, control variables are Firm Size, Firm Age, and Tangibility. These variables have confirmed by (Abobakr \& Elgiziry, 2015). Some other researchers also have been taken same independent variable for their study(Elabed \& Chokri, 2017). (Tarus \& Ayabei, 2015), have been identified Board Size, Board Independence, CEO Duality, and Board Tenure as an independent variables for the study and Firm size and Firm age as control variables. The Fixed effect multiple regression models (OLS) have used to analyze of the data. The researcher followed the model as,

$\mathrm{TFL}=\beta 0+\beta 1(\mathrm{BS})+\beta 2(\mathrm{NEX})$ $+\beta 3($ INEX) $+\beta 4$ (CEOD) $+\beta 5$ $(\mathrm{BFE})+\beta 6(\mathrm{BTN})+\beta 7(\mathrm{FS})+$ $\beta 8(\mathrm{FAG})+\beta 09(\mathrm{TAN})+\varepsilon$ 


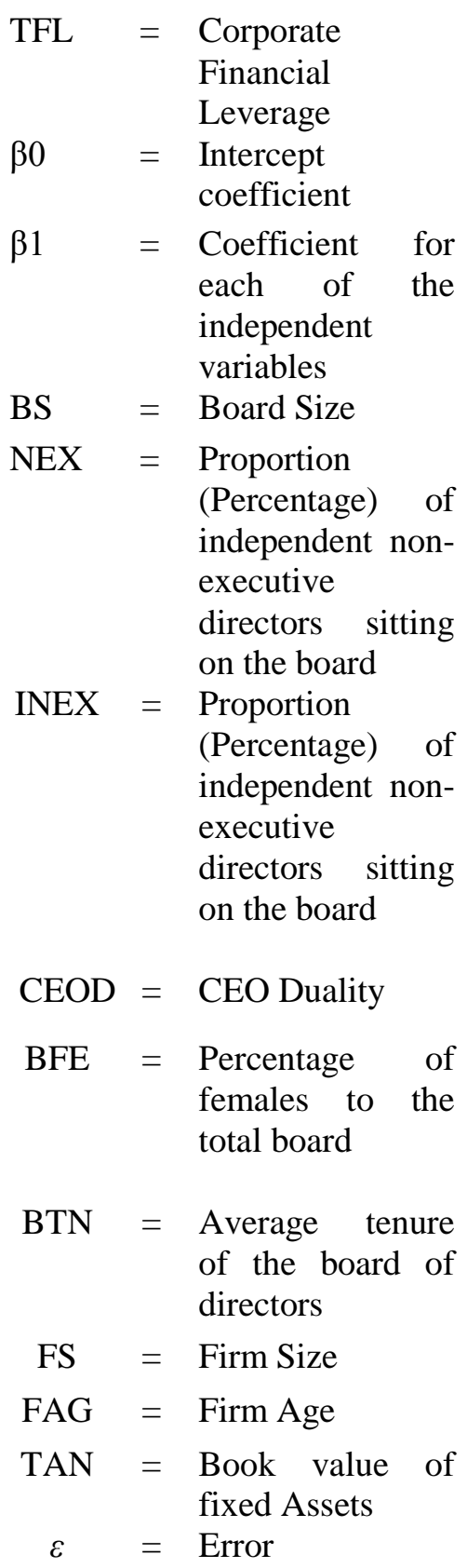

\section{RESULTS}

Before analysis of the relationship among the board characteristics and corporate financial leverage, it is essential to check the stationery of the data. Levin, Lin, and Chu (2002) test to find out the stationary of the data set. For the purpose of that researcher has used hypothesis as,

Null Hypothesis; Panel Data has a unite root.

Alternative Hypothesis; Panel Data has no unit root

Table 1: Summary of unit root test

\begin{tabular}{|c|c|c|c|}
\hline Variables & $\begin{array}{c}\text { P- Value } \\
\text { Levin, } \\
\text { Lin \& } \\
\text { Chu t* }\end{array}$ & Stationary & $\begin{array}{c}\text { Test } \\
\text { for } \\
\text { Unite } \\
\text { root }\end{array}$ \\
\hline TFL & 0.0000 & $\checkmark$ & $\mathrm{I}(0)$ \\
\hline BS & 0.0000 & $\checkmark$ & $\mathrm{I}(0)$ \\
\hline NEX & 0.0000 & $\checkmark$ & $\mathrm{I}(0)$ \\
\hline INEX & 0.0000 & $\checkmark$ & $\mathrm{I}(0)$ \\
\hline BFE & 0.0000 & $\checkmark$ & $\mathrm{I}(0)$ \\
\hline BTN & 0.0000 & $\checkmark$ & $\mathrm{I}(0)$ \\
\hline FS & 0.0000 & $\checkmark$ & $\mathrm{I}(0)$ \\
\hline FAG & 0.0000 & $\checkmark$ & $\mathrm{I}(0)$ \\
\hline TAN & 0.0000 & $\checkmark$ & $\mathrm{I}(0)$ \\
\hline CEOD & 0.1988 & $\mathrm{X}$ & \\
\hline
\end{tabular}

Source: Annual audited financial reports 2011 to 2019. 
Less than $0.05(5 \%)$ p-value of the unite root test indicates, the null hypothesis is rejected, while the alternative hypothesis is not rejected. It means that the data series is stationary. Conversely, when the p-value of the unit root test is more than $0.05(5 \%)$, the null hypothesis is accepted. It implies that the alternative hypothesis is rejected. Suggesting that the data series is nonstationary.

\subsection{Descriptive Analysis}

When considering Corporate Financial Leverage that the total debt to assets shows that overall mean of $41.60 \%$ and it indicates Non-Financial Listed Entities in Sri Lankan corporations depend more on equity financing than debt. When specifying the characteristics of the board it shows that Maximum board members are limited to 15 while Minimum members are 4 with average about 8 members. The Independent directors are ranging Minimum 11 percent and Maximum of 100 percent with overall mean value $37.70 \%$ indicating that from the total board members in the board, $37.70 \%$ are independent directors. Non-Executive nonindependent directors are ranging from $0 \%$ to $100 \%$ with a mean value of $30.81 \%$. Implication is such that the majority of the company board represent Independent Directors than NonExecutive directors. CEO duality records about 10 percent indicating that 10 percent of the sample has the CEO and the board chair as the same person. According to the Code of best practice on corporate governance in Sri Lanka, it is stated that there should be a clear division of responsibilities among the chairman and CEO. $10 \%$ is not a significant amount and it indicates most of the companies segregated their authority level of those two possessions. Since no individual can use unfettered power. Female percentage in the board is ranging $0 \%$ to $77.77 \%$ and averaging amounting about 8 $\%$. That shows that every public listed company is giving about 8 $\%$ opportunity to female directors to represent the board. 
Perera L.T.D., Wanigasekara W.A.D.K.J., \& Priyadarshani G.K.N., Wayamba Journal of Management 12 (1)

Table 2: Descriptive Analysis

\begin{tabular}{|c|c|c|c|c|c|}
\hline & Mean & Median & Maximum & Minimum & Std. Dev \\
\hline TFL & 41.60266 & 37.04668 & 851.3850 & 0.100606 & 64.35729 \\
\hline BS & 8.478889 & 8.000000 & 15.00000 & 4.000000 & 1.962552 \\
\hline NEX & 30.81437 & 28.57143 & 100.0000 & 0.000000 & 19.38136 \\
\hline INEX & 37.70374 & 36.36364 & 100.0000 & 11.11111 & 13.08961 \\
\hline BFE & 8.147557 & 8.012821 & 77.77778 & 0.000000 & 10.39929 \\
\hline BTN & 28.07660 & 28.00000 & 56.71429 & 13.54545 & 4.660551 \\
\hline FS & 15.51139 & 15.52447 & 18.94857 & 12.71292 & 1.073561 \\
\hline FAG & 3.044665 & 3.178054 & 4.510860 & 0.000000 & 0.822010 \\
\hline TAN & 86.96741 & 30.93778 & 45551.73 & 0.000000 & 1517.511 \\
\hline CEOD & 0.105556 & 0.00000 & 1.000000 & 0.000000 & 0.307439 \\
\hline
\end{tabular}

Source: Annual audited financial reports - 2011 to 2019

\subsection{Hausman Test}

Researcher required knowing which effect (fixed or random effect) shall use, before running a regression model with using cross sectional/Panel data. For that researcher can use the Hausman Test. If the P-value of the Hausman Test is less than 0.05 , (5\%) that implies that the researcher needs to select the
Fixed Effect and if the P-value of the Hausman Test is greater than $0.05(5 \%)$ researcher should select the random effect. Hypotheses that can be tested here are,

Null; Random effect is appropriate.

Alternative; Fixed effect is appropriate can be used 
Perera L.T.D., Wanigasekara W.A.D.K.J., \& Priyadarshani G.K.N., Wayamba Journal of Management 12 (1)

Table 3: Hausman Test (TL)

\begin{tabular}{|c|c|c|c|}
\hline \multicolumn{4}{|c|}{ Correlated Random Effects - Hausman Test } \\
\hline \multirow{3}{*}{ Test cross-section random effects } \\
\hline Test Summary & Chi-Sq. Statistic & $\begin{array}{c}\text { Chi-Sq. } \\
\text { d.f. }\end{array}$ & Prob. \\
\hline Cross-section random & 35.953935 & 09 & 0.0000 \\
\hline
\end{tabular}

Source: Annual audited financial report 2011 to 2019

According to the above results, the dependent variable (TFL) Pvalues less than $0.05(5 \%)$. Hence, Null Hypothesis is rejected and Alternative Hypothesis is not rejected.

Therefore, the researcher needs to consider the fixed effect regression in order to further analysis of the model.

\subsection{Regression Analysis.}

According to the Best Model of Regression Analysis (Fixed Effect Method) coefficient of determination, $\mathrm{R}^{2}$ about 0.88 $(88 \%) . \quad \mathrm{R}^{2}$ indicated that the changing of the TFL is decided $88 \%$ by the independent variables of this study. According to the regression analysis, $p$-value of the some variables was less than .05000 and hence null hypothesis were rejected while alternative hypothesis were accepted. That means changing in those variables have a significant impact on corporate Financial Leverage. Here BS, NEX, INEX, FAG, \& TAN create positive impact on corporate Financial Leverage while BFE, BTN, FS \& CEOD creates negative impact on corporate Financial Leverage. Probability value of Nonexecutive directors is lower than 0.0500 , ( $\mathrm{p}$-value $=0.0260$ ) hence significant to the TFL. P-value of INEX is lower than the $0.05(5 \%)$, $(\mathrm{P}$-value $=0.0144)$ meaning independent Non-Executive directors having a significant impact on the TFL. The BTN is having a significant impact to the TFL ( $\mathrm{p}$-value $=0.0371)$ since the $\mathrm{P}$-value of BTN is lower than the $0.05(5 \%)$. 
Perera L.T.D., Wanigasekara W.A.D.K.J., \& Priyadarshani G.K.N., Wayamba Journal of Management 12 (1)

Table 4: Regression Analysis

\begin{tabular}{|c|c|c|c|c|}
\hline \multicolumn{5}{|c|}{ Dependent Variable: TL } \\
\hline \multicolumn{5}{|c|}{ Method: Panel Least Squares } \\
\hline \multicolumn{5}{|c|}{ Sample: 20112019} \\
\hline \multicolumn{5}{|l|}{ Periods included: 9} \\
\hline \multicolumn{5}{|c|}{ Cross-sections included: 100} \\
\hline \multicolumn{5}{|c|}{ Total panel (balanced) observations: 900} \\
\hline Variable & Coefficient & Std. Error & t-Statistic & Prob. \\
\hline $\mathrm{C}$ & 32.98150 & 42.70521 & 0.772306 & 0.4402 \\
\hline $\mathrm{BS}$ & 0.434345 & 1.035614 & 0.419408 & 0.6750 \\
\hline NEX & 0.187644 & 0.084135 & 2.230277 & 0.0260 \\
\hline INEX & 0.290467 & 0.118392 & 2.453440 & 0.0144 \\
\hline CEOD & -87.24725 & 8.880799 & -9.824256 & 0.0000 \\
\hline $\mathrm{BFE}$ & -0.211624 & 0.179644 & -1.178018 & 0.2391 \\
\hline BTN & -0.636981 & 0.305090 & -2.087845 & 0.0371 \\
\hline $\mathrm{FS}$ & -0.034646 & 3.172373 & -0.010921 & 0.9913 \\
\hline FAG & 5.764885 & 3.927112 & 1.467970 & 0.1425 \\
\hline TAN & $8.93 \mathrm{E}-05$ & 0.000564 & 0.158315 & 0.8742 \\
\hline \multicolumn{5}{|c|}{ Effects Specification } \\
\hline \multicolumn{5}{|c|}{ Cross-section fixed (dummy variables) } \\
\hline $\begin{array}{l}\text { R-squared } \\
\text { Adjusted R- } \\
\text { squared } \\
\text { Durbin-Watson } \\
\text { stat } \\
\text { Prob(F-statistic) }\end{array}$ & & & & $\begin{array}{l}0.877706 \\
0.861009 \\
0.525803 \\
0.000000\end{array}$ \\
\hline
\end{tabular}

Source: Annual audited financial reports - 2011 to 2019

\subsection{Hypotheses}

H1: There is a significant positive impact of board size on corporate financial leverage.

H2: There is a significant negative impact of proportion of females on the board on corporate financial leverage

H3: There is a significant positive impact of proportion of board non-executive directors on corporate financial leverage
H4: There is a significant positive impact of Board independence on corporate financial leverage

H5: There is a significant positive impact of CEOs duality on corporate financial leverage

H6: There is a significant positive impact of board tenure on Corporate Financial Leverage 
Perera L.T.D., Wanigasekara W.A.D.K.J., \& Priyadarshani G.K.N., Wayamba Journal of Management 12 (1)

Table 5: Results of Regression

\begin{tabular}{|c|c|c|c|}
\hline Hypothesis & Significance level & Impact & Result \\
\hline H1: & 0.6750 & Positive & Rejected \\
\hline H2: & 0.2391 & Negative & Rejected \\
\hline H3: & 0.0260 & Positive & Accepted \\
\hline H4: & 0.0144 & Positive & Accepted \\
\hline H5 & 0.0000 & Negative & Rejected \\
\hline H6: & 0.0371 & Negative & Rejected \\
\hline
\end{tabular}

Source: Compiled by authors

\section{DISCUSSION}

Total Financial Leverage is significant and positively related to the proportionate of independent directors. Further, results show that maintaining debt policies, Non-Executive independent directors ensure the accountability of inside directors. This positive relationship was accepted by the research study in Sri Lanka. It indicated that listed manufacturing companies proportionate of Non-Executive directors and leadership style have positive relationship with leverage (Rajendran, 2012). However, contrast results found by another researcher. In the Sri Lankan context outside non-executive directors have a negative impact upon Sri Lankan companies" debt levels. Further CEO variable is positive and statistically significant and CEO Duality is increasing the debt usage
(Wellalage \& Locke, 2012) Independent directors are more likely to use higher leverage because of the networks they have access to and their ability to link the firm with providers of debt capital (Tarus \& Ayabei, 2015). This supported the researcher's conclusion. Accordingly, the third and fourth Hypothesis have been accepted. According to the findings of the research, Total Financial Leverage has a significant and negative relationship with CEO duality. Once the CEO and Chairperson are of the same particular character then it is easy to take a loan from outside. If the CEO holds dual authority, then it is flexible to generate external funds. This argument was accepted by the (Uddin, UddinKhan, \& Mosharrof, 2019). Since the study identified a significant negative 
relationship, the fifth hypothesis has been rejected. Further, researchers have identified tangibility is not a significant factor to influence corporate financial leverage and the same thing confirmed by (Vijeyaratnam \& Anandasayanan, 2015) with special reference to listed manufacturing companies in Sri Lanka. In this study researchers have identified board tenure has negative impact to the corporate financial leverage and it is statistically significant. Most of the researchers have identified board tenure has a significant positive impact on corporate financial leverage (Tarus \& Ayabei, 2015) . Since, the final hypothesis has been rejected.

\section{CONCLUSION}

The findings of the research can be applicable to the companies, which are actively trading Nonfinancial listed companies in Colombo stock exchange. The overall results gave the conclusion that the board characteristics played a vital role in determining corporate Financial Leverage of Sri Lankan Non-Financial Listed firms.

\section{RECOMMENDATION}

This research paper article may give a border idea about how a company can use corporate governance practices regarding the composition of the board of directors for adding additional value to the entity as a whole.
When a company wants to maintain a lower level of leverage within the organization, it is recommended to appoint directors who have good experience about the industry. Experienced board members may lead to better management strategic decisions and keep lower level of leverage. Ownership structure of an organization is a critical factor to its owners. To raise the funds the company can issue new equity shares and it will result in changing the company ownership structure. Hence, it has recommended to appoint more independent directors and nonexecutive directors in order to maintain the existing ownership structure. Since, they are more likely to raise funds from external sources rather than issuing new equity shares. Further, study has found female director's representations on the board are at a very lower level. Since, policy makers should take appropriate actions to enhance the level of participation of females to the board.

\section{REFERENCES}

Abobakr, M. G., \& Elgiziry, K. (2015, November 20). The Effect Of Board Characteristics and Owner Ship Structure on the Corporate Financal Leverage. Accounting and Finance Research , 5(1), 1-14. 
doi:https://doi.org/10.5430 /afr.v5n $1 \mathrm{p} 1$

Abor, J. (2007, February 27). Corporate Governance and Financing Decisions of Ghanaian Listed Firms. The International Journal of Businessin Society, $7(1)$ 83-92. doi:10.1108/14720700710 727131

Achchuthan, S., Kajananthan, R., \& Sivathaasan, N. (2013, October 25). Corporate Governance Practices and Capital Structure: A Case in Sri. International Journal of Business and Management, 8(21), 114125. Retrieved from http://creativecommons.or g/licenses/by/3.0/

Ahern, K. R., \& Dittmar, A. K. (2011, May 20). The Impact on Firm Valuation of Mandated Female Board Representation. Quarterly Journal of Economics, 127(1), 137197. Retrieved from https://papers.ssrn.com/sol 3/papers.cfm?abstract_id= 1364470

Ajanthan, A. (2013). Impact of Corporate Governance Practices on Firm Capital Structure and Profitability: A Study of Selected Hotels and Restaurant
Companies in Sri Lanka. Research Journal of Finance and Accounting, 4(10), 115-126. Retrieved from https://papers.ssrn.com/sol 3/papers.cfm?abstract_id= 2381183

Alvesa, P., \& Couto, E. B. (2014, January 16). Board of directors' composition and financing choices. 1-58. Retrieved from https://mpra.ub.unimuenchen.de/52973/

Berge, P., Ofek, E., \& Yermack, D. L. (1995). Managerial entrenchment and capital structure decisions. The Journal of Finance, 52(4), 1411-1438. Retrieved from

https://ideas.repec.org/a/bl a/jfinan/v52y1997i4p1411 $-38 . h t m l$

Buvanendra, S. (2013). capital Structure determinants Evidence from manufacturing and service sector companies in Srilanka. An international multidisciplinary research journal, 3, 83-99.

Colombage, S. R. (2007, March 13). Consistency and controversy in corporate financing practices: Evidence from an emerging market. Studies 
in Economics and

Finance, 24(1), 51-71.

Retrieved from

https://doi.org/10.1108/10

867370710737382

Dissanayake,

A. $\quad . ., \quad \&$

Dissanayake, T. S. (2019, June 26). Impact of Selected Board Characteristics on firm Performances Listed Manufacturing Firms in Sri Lanka. International Conference on Business Research, 54-58. Retrieved from http://dl.lib.uom.lk/bitstre am/handle/123/14753/105.pdf? sequence $=1 \&$ is All owed $=\mathrm{y}$

E. I., \& Chokri, S. (2017, September ). Impact of Firm Specificities and Board Characteristics on Corporate Financial Leverage: Case of Tunisian Listed Firms. International Journal of Management and Applied Science, 3(9), 56-60.

Exchange, C. S. (2019). GICS Industry Groups. Retrieved March 10, 2020, from CSE Colombo Stock Exchange: https://www.cse.lk/home/ CSESectors

Hanh Song , T., \& Nguyen, D. (2019, December 4). The effects of corporate governance mechanisms on the financial leverageprofitability relation : Evidence from Vietnam. Management Research Review, 43(4), 387-409. Retrieved from https://doi.org/10.1108/M RR-03-2019-0136

Harris, C. K. (2014). Women Directors on Public Company Boards: Does a Critical Mass Affect Leverage? Northeastern Association of Business, Economics and Technology (pp. 139-154). Business and Economics Faculty Publications. . Retrieved from https://digitalcommons.urs inus.edu/bus_econ_fac/29

Hsien, C., Wang , L.-H., \& Liu, H.-W. (2012, February 1). Corporate Governance and Capital Structure. Review of Economics \& Finance. Retrieved from http://www.bapress.ca/ref/ ref-2012-

3/Corporate\%20Governan ce\%20and\%20Capital $\% 20$ Structure---

Evidence\%20from\%20Tai wan\%20SMEs.pdf

Jensen, M. C. (1986, May). Agency Costs of Free Cash Flow Corporate Finance, and Takeovers. 
American Economic

Review, 76(2), 323-329.

Retrieved from

http://papers.ssrn.com/abst ract $=99580$.

John , G. R., \& Campbell, R. H. (1999, December 10). The theory and practice of corporate

finance:evidence from the field. Journal of Financial Economics, 187-243.

Lückerath-Rovers, M. (2013). Women on Boards and Company Performance. Journal of Management \& Governance, 17(2), 491509. doi:10.1007/s10997011-9186-1

Mokarami , M., Ahmadi, M. R., \& Hosseinzadeh, A. H. (2012, July). Corporate Governance and Financial Decision Making in the Firms Listed on Tehran Stock Exchange. International Research Journal of Finance and Economics, 95.

Monther , J. S. (2015, May). Corporate Governance Practices and Capital Structure A Study with Special Referenceto Board Size, Board Gender, Outside Director and CEO

Duality. International Journal of Economics,Commerce and
Management United Kingdom, 3(5), 264-273. Retrieved from http://ijecm.co.uk/wpcontent/uploads/2015/05/3 516.pdf

Nadeem , S. A., \& Zongjun, W. (2012, October 12). Effects of corporate governance on capita structure. 12(5), 629-641. Retrieved from https://doi.org/10.1108/14 720701211275569

Rajendran, K. (2012). Effect of corporate governance on capital structure: case of the Sri Lankan listed manufacturing companies. Journal of Arts, Science \& Commerce.

Ross, S. A., Thompson, S. C., Christensen, M. J., Westerfield, R. W., \& Jordan, B. D. (1994). Long Term Financial Planning and Growth. In S. A. Ross, S. C. Thompson, M. J. Christensen, R. W. Westerfield, \& B. D. Jordan, Fundamental of Coporate Finance (p. 842). , Australia: Ann Nolan.

Ross, S. A., Westerfield, R. W., \& Jaffe, J. (2005). Corporate Finance. In The Pecking order Theory (Seventh 
ed., pp. 480-451). McGraw Hill Publishing Company.

Shapiro, A. C., \& Balbirer, S. D. (2000). Agency cost and capital Structure. In Modern Corporate Finance (pp. 486-487). Pearson Education (singapore).

Sheikh , N. A., \& Wang, Z. (2012, October 12). Effects of corporate governance on capital structure : empirical evidence from Pakistan. 12(5), 629-641. Retrieved from https://doi.org/10.1108/14 720701211275569

Tarus, D. K., \& Ayabei, E. (2015, December 15). Board composition and capital structure: evidence from Kenya. Management Research Review, 39(9), 1056-1079. Retrieved from https://doi.org/10.1108/M RR-01-2015-0019

Thi Pham, H. S., \& Nguyen, D. T. (2019, December 19). The effects of corporate governance mechanisms on the financial leverageprofitability relation: Evidence from Vietnam. ISSN: 2040-8269, 43(4), 387-409. doi:https://doi.org/10.1108 /MRR-03-2019-0136

Uddin, M. N., UddinKhan, M. S., \& Mosharrof, H. (2019, September 13). Does Corporate Governance Influence Leverage Structure in Bangladesh? International Journal of Financial Studies, 1-16. Retrieved from www.mdpi.com/journal/ijf $\mathrm{s}$

Usman, M., Farooq, M. U., Zhang, J., Majid Makki, M., \& Khan, M. K. (2019, Aprile 30). Female directors and the cost of debt: does gender diversity in the boardroom matter to lenders? Managerial Auditing Journal, 34(4), 374-392. doi:10.1108/MAJ-042018-1863

Uwalomwa, U. (2014, April). Corporate Governance and Capital Structure: Evidence from Listed Firms in Nigeria Stock Exchange. Journal of Accounting and Management, 4(1), 5-14. Retrieved from https://ideas.repec.org/a/d ug/jaccma/y2014i1p514.html

Vakilifard, Gerayli, Yanesari, \& Ma'toufi, A. (2011). 
Perera L.T.D., Wanigasekara W.A.D.K.J., \& Priyadarshani G.K.N., Wayamba Journal of Management 12 (1)

Effect of Corporate Governance on Capital

Structure Case of the Iranian Listed Firms.

Vijeyaratnam, H., \&

Anandasayanan, S. (2015). The Determinants of Leverage of Sri Lankan Manufacturing. Research Journal of Finance and Accounting, 6(5), 189195.

Wellalage, N. H., \& Locke, S. M. (2012, July 23). Corporate Governance and Capital Structure Decision of Sri Lankan Listed Firms. 157169. Retrieved from http://ssrn.com/abstract=2 115260

Wilson, N., \& Altanlar, A. (2009, September 22). Director Characteristics, Gender Balance and Insolvency Risk. Retrieved from http://dx.doi.org/10.2139/s srn.1932107 